\title{
Bioethanol potentials from marine residual biomass: an Emergy evaluation
}

\author{
F. Coppola, E. Simoncini \& R. M. Pulselli \\ Department of Chemistry, University of Siena, Siena, Italy
}

\begin{abstract}
Different types and sources of biofuels were recently studied as potential energy issues. The aim of this work is to evaluate the use of new kinds of renewable and alternative feedstocks for producing bioethanol. In particular, the potential production of bioethanol from cellulosic material was analyzed considering two species of macroalgae (C. linum, G. longissima) as residual biomass from an eutrophic lagoon system. Besides chemical analyses and the evaluation of yields in producing bioethanol, accounting methods are necessary to understand the level of sustainability of the whole production process exploiting natural resources. An assessment was carried out based on the emergy approach, in order to evaluate the environmental performance of processes in the case study. Results showed that macroalgae are a good candidate for bioethanol production even if bioethanol conversion from macroalgae biomass was found to be not very efficient per se. Nevertheless, the feedstock may be involved in processes of biorefinery in systems with a high carbohydrate content, in which heat necessary to treat the feedstock and maintain the micro organisms performing the transformation are provided by external sources already existing (e.g. a combined heat and power plant).
\end{abstract}

Keywords: biofuels, macroalgae, biorefinery, emergy analysis.

\section{Introduction}

In Europe, the transport sector accounts for around 30\% of the total energy consumption and biofuels have been increasingly investigated in recent years. The EU Commission has estimated that there is a great potential for biofuels production (from the actual $2 \%$ of the total amount of used fuels, to the target of $25 \%$ in 2030) [1]. The estimations assumed a land use between 4 and $18 \%$ of the 
total EU agricultural land to produce biomass for energy purposes in order to replace the share of fossil sources required by the directive 2003/30/CE [2].

A coordinated strategy for biofuel production, particularly in the transport sector, is needed. Therefore, sustainable technologies to produce biofuels from different kinds of biomass resources are needed. A number of methodologies should be considered in order to assess the level of sustainability of different processes. In addition to technical and economic analyses (e.g. [3]), it is also important to evaluate sustainability in the long run based on resource consumption.

Biofuels may be characterized as the well-established $1^{\text {st }}$ generation (G1) biofuels from starch and sugars and the developing $2^{\text {nd }}$ generation biofuels (G2) from lignocellulosic material. An annual growth rate is expected for liquid biofuels around $6.3 \%$ between 2005 and 2030 and the bioethanol will be the largest share of them [4]. G2 products come from lignocellulosic material in wood, straw and municipal waste [5]. In 2003, about $61 \%$ of the world's bioethanol was derived from sugar crops: sugar cane (Brazil), sugar beet (France) and molasses. The remaining 39\% was produced from grains, predominantly maize (USA) [6]. Lignocellulosic material has a more complex structure than starch; this means that more expensive methods are required to transform the different kinds of sugar (C6 and C5 sugars) in G2 bioethanol production technologies. Today, lignocellulosic processing is well advanced, and the EU has three demonstration plants, in Sweden, Spain and Denmark [5]. The aim of this paper is to test second-generation bioethanol productions using marine biomass (macroalgae) from a chemical and a sustainability point of view, by means of an Emergy based approach. The Emergy methodology introduced by Odum [7-9] is a sustainability assessment based on estimating the exploitation of natural resources and the amount of basic energy (solar) directly or indirectly required to produce them. To our knowledge, however, there are a few attempts that used marine biomass for G2 bioethanol production, never analyzed before through an Emergy approach.

\section{Materials and methods}

\subsection{Study area}

Samples of two species of macroalgae, Chaethomorpha linum (Ulvophyceae) and Gracilaria longissima (Rhodophyceae) were collected in the Orbetello Lagoon, located in southern Tuscany $\left(42^{\circ} 25^{\prime}\right.$ and $42^{\circ} 29^{\prime}$ lat. $\mathrm{N}$ and $11^{\circ} 10^{\prime}$ and $11^{\circ} 17^{\prime}$ long.) that covers a total area of $25.25 \mathrm{~km} 2$. This system is divided in two communicating basins [10] and has $1 \mathrm{~m}$ average depth. Moreover, this is an important site for fish farming activities; especially because the entire lagoon achieved a certain level of eutrophication due to an intensive flow of nutrients (nitrogen and phosphorus); $\mathrm{N}$ and $\mathrm{P}$ flows originate from domestic treatment plants, urban phytotreatments, land based fishfarm outflows, eastern fishfarm phytotreatment outflows. In recent years there was an excessive macroalgal growth [11-13] that caused serious problems to the entire ecosystem. The 
harvesting of macroalgal biomass was thus necessary to reduce the ecological impact, and this activity is executed every year from June to November by 4 boats collecting approximately 40 tons per day of the two species with the following percentage composition: 60\% Gracilaria longissima; 40\% Chaetomorpha linum. The collection is estimated in 5000 metric tons of algae that are transported and confined in a landfill.

\subsection{Bioethanol potentials}

The two species of macroalgae C. linum, and G. longissima, were dried in a stove at $40^{\circ} \mathrm{C}$ for $48 \mathrm{~h}$. About $200 \mathrm{~g}$ (approximately $90 \% \mathrm{DM}$ ) of each species were milled to pass a $1 \mathrm{~mm}$ screen. Analyses were performed in triplicate for each species, and conducted for both raw and pre-treated material, using a stirred and heated reactor $60 \%$ of dry matter per litre of water, $\mathrm{T} 195^{\circ} \mathrm{C}$, pressure $4 \mathrm{bar}$ $\mathrm{N}_{2}$, and 12 bar $\mathrm{O}_{2}$ and 10 min holding time.

Cellulose convertibility, through enzymatic hydrolysis, was carried out in a cabinet at $50{ }^{\circ} \mathrm{C}$, using raw material and the filter cake of the pretreated material of the two species; samples were analyzed using two enzymes, Celluclast and Novozym 188 for cellulose, and Spirizyme Plus Tech for starch, to convert the two complex structures into sugar monomers, glucose. The extracts were run to the HPLC.

\subsection{Emergy evaluation}

Emergy is a well-known methodology introduced by Odum [7,8], and it represents the total amount of available energy (i.e. exergy), of one kind, generally solar energy, directly or indirectly required to make a product or to support a process. It is not a state function, since it depends on the pathway that the process follows. In fact, the emergy of a product is related to the way it is produced. This methodology allows for the evaluation of different processes on a common basis, the solar energy necessary to obtain a product (see eqn. (1)); the basis of emergy evaluation is the conversion of all process inputs, including energy of different types and energy inherent in materials and services, into emergy by means of a conversion factor called transformity.

Unlike emergy, transformity is an intensive quantity, and is measured in sej $\mathrm{J}^{-1}$ (emergy per unit energy). It represents the inverse of an efficiency comparing two similar processes; a higher transformity means that more emergy is needed to produce the same amount of output (see eqn. (2)).

$$
\begin{aligned}
& E m_{k}=\sum_{i} \operatorname{Tr}_{i} E_{i} \\
& \operatorname{Tr}_{i}=\frac{E m_{i}}{E_{i}}
\end{aligned}
$$

In this way all inputs are converted into the solar equivalent energy needed to create the main energy inflows to a certain process; each flow is summed and multiplied by its transformity, and the result is the measurement of total 
resources (renewable and non-renewable) that have been necessary in order to obtain a product or a process.

\section{Results}

\subsection{Bioethanol theoretical yield}

Results from the HPLC analyses showed that C. linum species contains more glucose with respect to $\mathrm{G}$. longisima as reported in figure $1(\mathrm{G}=\mathrm{G}$. longissima, $\mathrm{C}=\mathrm{C}$. linum). To know the amount of bioethanol potential an indirect method was used; we used a conversion factor, 0.51 , that is the efficiency of conversion of glucose into bioethanol using yeast (Saccaromyces cerevisiae). By multiplying the glucose content found after HPLC analyses, for the conversion factor, 0.51, we obtain the estimated bioethanol yield, as reported in figure 1 . C. linum species showed an higher bioethanol potential with respect to G. longissima.

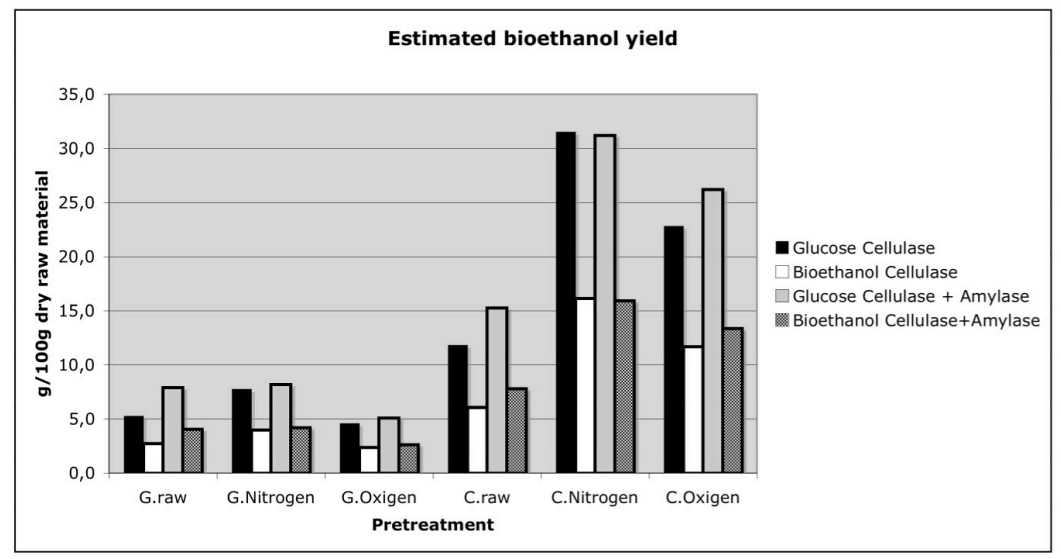

Figure 1: $\quad$ Estimated bioethanol yield (g/100 g dry matter) using different pre-treatment and enzymes, in the two species of macroalgae.

\subsection{Emergy}

To describe the flows of energy and matter in the systems under study, a model was developed in the form of an Energy System Diagram. Figure 2 shows the energy diagram of the macroalgae system in the Orbetello Lagoon with relations between natural resources and final product, accounting for all energy and material flows involved in macroalgae bioethanol production. The system (Figure 2) starts from the growth of macroalgae and the harvesting phase. The following table (Table 2) reports all inputs (expressed in joules and grams) referred to each component entering in the productive process. 


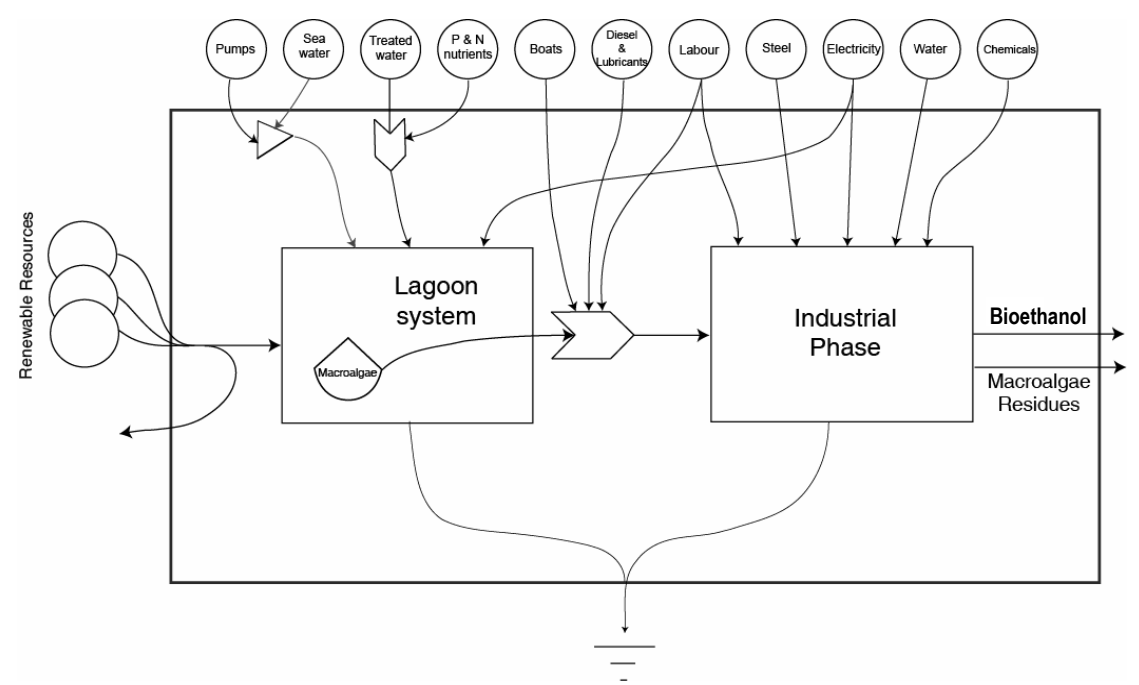

Figure 2: Energy system diagram of bioethanol production in the Orbetello Lagoon, from the harvesting to the industrial phase.

There are several inputs that contribute to the growth of macroalgae, both non-renewable (fossil based) and renewable (solar radiation, rain, wind, geothermal heat). Among natural renewables, only solar radiation and geothermal heat were considered in order to avoid a double counting. The higher emergy inputs, from non-renewable resources, are nitrogen and phosphorus flows, which indirectly feed the macroalgae bloom; the other higher inputs are steel for the harvesting boats ( 4 boats) and the electricity used by the ten pumps in order to increase water exchanges between the sea and the lagoon and to improve the oxygen concentration of the aquatic system. The emergy flow for this phase of the macroalgae system (Table 1) was $6.09 \mathrm{E}+18$ sej.

Thus, in the growing and harvesting phase, a high emergy flow is due to inputs of Nitrogen and Phosphoros. This quantity is generally used in intensive agricultural systems and was not expected in a natural ecosystem like a lagoon.

In the industrial phase, that is the bioethanol production from macroalgae, all the inputs $(\mathrm{J}$ and $\mathrm{g})$ were derived from the same inputs actually used to process wheat straw in G2 bioethanol production [14-17] and reported in table 2; we assumed that the same amount of inputs necessary for $1 \mathrm{~g}$ of dry straw is necessary for $1 \mathrm{~g}$ of dry macroalgae. There is a great consumption of nonrenewable inputs, first coal for steam and electricity used in the process, second concrete and steel for the conversion plant, followed by chemicals, enzymes and yeast, used for the conversion of cellulose into glucose and for the fermentation respectively. In the industrial phase of macroalgae the emergy flow was $2.57 \mathrm{E}+17 \mathrm{sej}$.

The total emergy flow required by the entire process of the macroalgae system was $6.35 \mathrm{E}+18 \mathrm{sej}$. Also in this case we divided the value of emergy flow for the energetic content of the total quantity of macroalgae bioethanol output 
Table 1: Emergy of bioethanol production in the Orbetello Lagoon.

\begin{tabular}{|c|c|c|c|c|c|}
\hline Input & Unit & Quantity & $\begin{array}{c}\text { Transformity } \\
\text { (sej unit }{ }^{-1} \text { ) }\end{array}$ & $\begin{array}{c}\text { Total Emergy } \\
\text { flow (sej year }{ }^{-1} \text { ) }\end{array}$ & Resources \\
\hline \multicolumn{6}{|c|}{ Growth and harvesting phase } \\
\hline Solar radiation & $\mathrm{J}$ & $1.11 \mathrm{E}+17$ & $1.00 \mathrm{E}+00$ & $1.11 \mathrm{E}+17$ & $\mathrm{R}$ \\
\hline Rain & g & $1.70 \mathrm{E}+13$ & $1.51 \mathrm{E}+05$ & $2.57 \mathrm{E}+18$ & $\mathrm{R}$ \\
\hline Wind & $\mathrm{J}$ & $2.21 \mathrm{E}+11$ & $2.52 \mathrm{E}+03$ & $5.56 \mathrm{E}+14$ & $\mathrm{R}$ \\
\hline Geothermal heat & $\mathrm{J}$ & $1.20 \mathrm{E}+14$ & $4.28 \mathrm{E}+03$ & $5.12 \mathrm{E}+17$ & $\mathrm{R}$ \\
\hline Nitrogen & $\mathrm{g}$ & $1.08 \mathrm{E}+08$ & $2.41 \mathrm{E}+10$ & $2.60 \mathrm{E}+18$ & $\mathrm{~F}$ \\
\hline Phosphorus & $\mathrm{g}$ & $6.00 \mathrm{E}+06$ & $2.02 \mathrm{E}+10$ & $1.21 \mathrm{E}+17$ & $\mathrm{~F}$ \\
\hline Diesel & $\mathrm{J}$ & $2.01 \mathrm{E}+13$ & $1.10 \mathrm{E}+05$ & $2.21 \mathrm{E}+15$ & $\mathrm{~F}$ \\
\hline Lubricants & $\mathrm{J}$ & $1.00 \mathrm{E}+10$ & $1.10 \mathrm{E}+05$ & $1.10 \mathrm{E}+13$ & $\mathrm{~F}$ \\
\hline Steel (boat) & g & $4.40 \mathrm{E}+06$ & $1.13 \mathrm{E}+10$ & $4.97 \mathrm{E}+16$ & $\begin{array}{c}\mathrm{F} \\
10 \% \mathrm{R}\end{array}$ \\
\hline Human labor & $\mathrm{J}$ & $1.95 \mathrm{E}+09$ & $1.24 \mathrm{E}+07$ & $2.41 \mathrm{E}+16$ & $90 \% \mathrm{~N}$ \\
\hline Steel (pumps) & $\mathrm{g}$ & $6.00 \mathrm{E}+05$ & $1.13 \mathrm{E}+10$ & $6.78 \mathrm{E}+15$ & $\begin{array}{c}F \\
25 \% R\end{array}$ \\
\hline Electricity & $\mathrm{J}$ & $1.04 \mathrm{E}+12$ & $2.00 \mathrm{E}+05$ & $2.08 \mathrm{E}+17$ & $75 \% \mathrm{~F}$ \\
\hline $\begin{array}{l}\text { Total Emergy } \\
\text { phase } 1 \\
\text { Collected algae }\end{array}$ & g & $5.00 \mathrm{E}+09$ & $1.22 \mathrm{E}+09$ & $6.09 \mathrm{E}+18$ & \\
\hline \multicolumn{6}{|l|}{ Industrial phase } \\
\hline $\begin{array}{l}\text { Conversion plant } \\
\text { (steel) } \\
\text { Conversion plant }\end{array}$ & $\mathrm{g}$ & $5.98 \mathrm{E}+06$ & $1.13 \mathrm{E}+10$ & $6.75 \mathrm{E}+16$ & $\mathrm{~F}$ \\
\hline $\begin{array}{l}\text { (concrete) } \\
\text { Coal(Electricity } \\
+ \text { Steam }\end{array}$ & $\mathrm{g}$ & $1.06 \mathrm{E}+07$ & $1.81 \mathrm{E}+09$ & $1.92 \mathrm{E}+16$ & $\mathrm{~F}$ \\
\hline generation) & $\mathrm{J}$ & $4.00 \mathrm{E}+12$ & $3.98 \mathrm{E}+04$ & $1.59 \mathrm{E}+17$ & $\begin{array}{c}\mathrm{F} \\
10 \% \mathrm{R}\end{array}$ \\
\hline Human labor & $\mathrm{J}$ & $3.38 \mathrm{E}+07$ & $1.24 \mathrm{E}+07$ & $4.20 \mathrm{E}+14$ & $90 \% \mathrm{~N}$ \\
\hline Water & $\mathrm{g}$ & $2.38 \mathrm{E}+07$ & $1.25 \mathrm{E}+06$ & $2.97 \mathrm{E}+13$ & $\mathrm{~N}$ \\
\hline $\begin{array}{l}\text { Enzymes } \\
\text { (amylase) J oil } \\
\text { Enzymes }\end{array}$ & $\mathrm{J}$ & $2.70 \mathrm{E}+09$ & $5.40 \mathrm{E}+04$ & $1.46 \mathrm{E}+14$ & $\mathrm{~F}$ \\
\hline (cellulase) J oil & $\mathrm{J}$ & $5.56 \mathrm{E}+09$ & $5.40 \mathrm{E}+04$ & $3.00 \mathrm{E}+14$ & $\mathrm{~F}$ \\
\hline $\begin{array}{l}\text { Sulphuric acid } \\
\text { Phosphorous }\end{array}$ & $\mathrm{g}$ & $5.84 \mathrm{E}+06$ & $3.80 \mathrm{E}+08$ & $2.22 \mathrm{E}+15$ & $\mathrm{~F}$ \\
\hline $\begin{array}{l}\text { acid } \\
\text { Sodium }\end{array}$ & $\mathrm{g}$ & $1.36 \mathrm{E}+06$ & $3.80 \mathrm{E}+08$ & $5.17 \mathrm{E}+14$ & $\mathrm{~F}$ \\
\hline Hydroxide & $\mathrm{g}$ & $8.80 \mathrm{E}+05$ & $3.80 \mathrm{E}+08$ & $3.34 \mathrm{E}+14$ & $\mathrm{~F}$ \\
\hline Ammonia water & $\mathrm{g}$ & $2.80 \mathrm{E}+06$ & $3.80 \mathrm{E}+08$ & $1.06 \mathrm{E}+15$ & $\mathrm{~F}$ \\
\hline $\begin{array}{l}\text { Urea } \\
\text { Calcium }\end{array}$ & $\mathrm{g}$ & $1.36 \mathrm{E}+06$ & $3.80 \mathrm{E}+08$ & $5.17 \mathrm{E}+14$ & $\mathrm{~F}$ \\
\hline Chloride & g & $2.80 \mathrm{E}+05$ & $3.80 \mathrm{E}+08$ & $1.06 \mathrm{E}+14$ & $\mathrm{~F}$ \\
\hline Yeast J oil & $\mathrm{J}$ & $1.01 \mathrm{E}+11$ & $5.40 \mathrm{E}+04$ & $5.46 \mathrm{E}+15$ & $\mathrm{~F}$ \\
\hline $\begin{array}{l}\text { Total Emergy } \\
\text { phase } 2\end{array}$ & & & & $2.57 \mathrm{E}+17$ & \\
\hline $\begin{array}{l}\text { Total Emergy } \\
\text { Output: } \\
\text { bioethanol }\end{array}$ & $\begin{array}{l}\mathrm{g} \\
\mathrm{J}\end{array}$ & $\begin{array}{l}6.87 \mathrm{E}+07 \\
1.83 \mathrm{E}+12 \\
\end{array}$ & $\begin{array}{l}9.24 \mathrm{E}+10 \\
3.46 \mathrm{E}+06 \\
\end{array}$ & $6.35 \mathrm{E}+18$ & \\
\hline
\end{tabular}


Table 2: $\quad$ Inputs necessary to treat $1 \mathrm{~g}$ of algae equal to treat $1 \mathrm{~g}$ of wheat straw.

\begin{tabular}{|l|r|c|}
\hline \multicolumn{1}{|c|}{ Inputs } & & Quantity for 1 g of dry algae \\
\hline Conversion plant (steel) & $\mathrm{g}$ & $7.47 \mathrm{E}-03$ \\
\hline Conversion plant (concrete) & $\mathrm{g}$ & $1.33 \mathrm{E}-02$ \\
\hline Coal (steam+electricity) & $\mathrm{J}$ & $5.01 \mathrm{E}+03$ \\
\hline Human labour & $\mathrm{J}$ & $4.23 \mathrm{E}-02$ \\
\hline Water & $\mathrm{g}$ & $2.97 \mathrm{E}-02$ \\
\hline Enzymes (amylase) J oil & $\mathrm{J}$ & $3.37 \mathrm{E}+00$ \\
\hline Enzymes (cellulase) J oil & $\mathrm{J}$ & $6.95 \mathrm{E}+00$ \\
\hline Sulphuric acid & $\mathrm{g}$ & $7.30 \mathrm{E}-03$ \\
\hline Phosphorous acid & $\mathrm{g}$ & $1.70 \mathrm{E}-03$ \\
\hline Sodium Hydroxide & $\mathrm{g}$ & $1.10 \mathrm{E}-03$ \\
\hline Ammonia water & $\mathrm{g}$ & $3.50 \mathrm{E}-03$ \\
\hline Urea & $\mathrm{g}$ & $1.70 \mathrm{E}-03$ \\
\hline Calcium Chloride & $\mathrm{g}$ & $3.50 \mathrm{E}-04$ \\
\hline Yeast J oil & $\mathrm{J}$ & $1.26 \mathrm{E}+02$ \\
\hline
\end{tabular}

$(1.83 \mathrm{E}+12 \mathrm{~J}$ per $68,700 \mathrm{~kg}$ of bioethanol); we obtained the value for the transformity, which is $3.46 \mathrm{E}+06$ sej $\mathrm{J}^{-1}$.

\section{Conclusions}

The aim of an Emergy analysis is to evaluate the exploitation of natural resources (renewable and non-renewable) used up in a given process.

Two main phases in the process of second-generation bioethanol production were considered. Regarding the first phase of macroalgae growth and harvesting, results highlighted high emergy values but, in the case of Orbetello, macroalgae can be considered residual biomass. The harvesting process of macroalgae is a procedure necessary to manage and maintain other activities in the Orbetello lagoon. It is however performed independently from the bioethanol production. For this reason, inputs involved in the growth and harvesting phase should not be considered. Therefore, we can consider that the real emergy investment [18] is the given by emergy use in the industrial phase in which only the inputs involved in bioethanol production were taken into account. Therefore, the total emergy flow necessary for the production of macroalgae was $6.35 \mathrm{E}+18$ sej but the real emergy investment of final bioethanol output was $2.57 \mathrm{E}+17$ sej $\mathrm{J}-1$. In this case the transformity of the final product (bioethanol) was equal to $1.40 \mathrm{E}+05$ sej J-1 instead of $3.46 \mathrm{E}+06$ sej $\mathrm{J}-1$. 
Table 3: Transformity values and Environmental Loading Ratios (ELRs) from other published emergy assessments of G1 bioethanol production.

\begin{tabular}{|l|l|l|l|}
\hline Transformity $10^{5}$ sej J $^{-1}$ & ELR & Feedstock & Authors \\
\hline 1.03 & 3.27 & Sugar cane (Brazil) & Bastianoni et al. [19] \\
\hline 1.40 & 6.04 & Sugar cane (Florida) & Bastianoni et al. [19] \\
\hline 0.93 & 1.57 & Sugarcane (Louisiana) & Bastianoni et al. [19] \\
\hline 7.62 & 13.63 & Grapes (Italy) & Bastianoni et al. [19] \\
\hline 1.07 & - & Corn & Ulgiati [20] \\
\hline
\end{tabular}

Emergy assessment of first generation technology to produce bioethanol from sugar cane (Florida, Brazil, and Louisiana) and from grapes (Italy) was carried out by Bastianoni et al. [20], whereas Ulgiati [21] studied maize as feedstock. Values were reported in Table 3.

Previous calculated transformities in the range from 0.93 to $1.40 \mathrm{E}+05$ sej J $\mathrm{J}^{-1}$ (omitting grapes) were similar (same order of magnitude) to the transformity

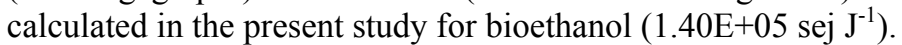

The Environmental Loading Ratio (ELR), the ratio between the nonrenewable Emergy flow and the renewable one, was then used as an index to measure the environmental pressure (it is generally high for a system with a high level of technology used). In the case of the second-generation bioethanol production, the ELR was 1.0, a lower value with respect to those reported in table 3 and referred to the first generation technology.

Emergy based results showed that, considering transformity and ELR, macroalgae represent a good potential resource for bioethanol production especially in the case of the Orbetello lagoon.

\section{References}

[1] Biofuels in the European Union. A vision for 2030 and beyond- final report of the Biofuels Research Advisory Council. 2006. ftp://ftp.cordis. europa.eu/pub/fp7/energy/docs/biofuels_vision_2030_en.pdf.

[2] European Parliament, Directive 2003/30/CE. Eur lex.europa.eu/LexUriServ/LexUriServ.do:IT:PDF

[3] Sassner, P., Galbe, M., Zacchi, G. Techno-economic evaluation of bioethanol production from three different lignocellulosic materials. Biomass and Bioenergy, 32, pp. 422-430, 2008.

[4] IEA, World energy outlook 2006, eds. Paris: International Energy Agency, pp. 385-417, 2006.

[5] Thomsen, A.B., Thomsen, M.H., Van Maarschalkerweerd, C., Skytte, K., Olsen, H.S., Christensen, B.H., Zacchi, G., Energy supply technologies. Bioethanol for transport. Risø Energy Report, pp. 49-53, 2007.

[6] Berg, C., World fuel ethanol analysis and outlook. The Online Distillery Network for Distilleries \& Fuel Ethanol Plants Worldwide, 2004. www.distill.com/World-Fuel-Ethanol-A\&O-2004.html. 
[7] Odum, H.T., Self organisation, transformity and information. Science; 242, pp. 1132-1139, 1988.

[8] Odum, H.T., Environmental Accounting. Emergy and Environmental Decision Making, New York: John Wiley and Sons, 1996.

[9] www.emergysociety.org/ Last access July $28^{\text {th }}, 2008$.

[10] Travaglia, C., Lorenzini, M., Monitoring algae growth by digital analysis of LANDSAT data: the Orbetello lagoon case study. RSC Series, ed. FAO, Rome, pp. 19, 1985.

[11] Lenzi, M., Experiences for the management of Orbetello lagoon: eutrophication and fishing. Science of the Total Environment, 5, pp.1189$1198,1992$.

[12] Bombelli, V., Lenzi, M., The Orbetello lagoon and the Tuscany coast (Chapter 123). Marine Benthic Vegetation. Ecological Studies, eds. Schramm, Nienhuis, pp. 331-337, 1996.

[13] Lenzi, M., Palmieri, R., Porrello, S., Restoration of the eutrophic Orbetello lagoon (Tyrrhenian Sea, Italy): water quality management. Marine Pollution Bulletin, 46, pp.1540-1548, 2003.

[14] Bentsen, N.S., Felby, C., Ipsen, K.H., Energy balance of $2^{\text {nd }}$ Generation bioethanol production in Denmark. Royal Veterinary and Agricultural University, Danish centre for Forest, Landscape and Planning and Elsam Engineering A/S, 2006.

[15] Jensen, K.H., Thyoe, K.A., $2^{\text {nd }}$ Generation Bioethanol for Transport: the IBUS concept. Boundary conditions and environmental assessment. Master thesis. Department of manufacturing Engineering and Management, Technical University of Denmark.

[16] http://www.man.dtu.dk/upload/institutter/ipl/publ/2.gen\%20bioethanol_for transport_report.pdf;

[17] Thomsen ,M.H, Thygesen, A., Thomsen, A.B., Hydrothermal treatment of wheat straw at pilot plant scale using a three-step reactor system aiming at high hemicellulose recovery, high cellulose digestibility and low lignin hydrolysis. Bioresource Technology, 99, pp. 4221-4228, 2008.

[18] Maarschalkerweerd, van C., Welfare economic perspectives of Danish bioethanol production - a technology specific analysis of greenhouse gas savings and supply security benefits of straw and wheat grain based bioethanol. Master thesis. Institute of Food and Resource Economics, Royal Veterinary and Agricultural University, Rolighedsvej, 71 pp., 2006.

[19] Marchettini, N., Ridolfi, R., Rusici, M., An environmental analysis for comparing waste management options and strategies. Waste Management, 27, pp. 562-571, 2007.

[20] Bastianoni, S., Marchettini, N., Ethanol production from biomass: analysis of process efficiency and sustainability. Biomass and Bioenergy, 11, pp. 411-418, 1996.

[21] Ulgiati, S., A Comprehensive Energy and Economic Assessment of Biofuels: When "Green', is not enough. Critical Reviews. Plant Sciences, 20, pp. 71-106, 2001. 